\title{
Controversies In Accounting For Post-Retirement Benefits
}

\author{
Sharon A. Bachan, Southwest Florida International Airport, USA \\ Margaret Briscoe, Royal Palm Bank of Florida, USA \\ Jackie Conrecode, Florida Gulf Coast University, USA \\ Ella Fleming, Qorval LLC, Naples, Florida, USA \\ Ara G. Volkan, Florida Gulf Coast University, USA
}

\begin{abstract}
SFAS 158 addresses certain reporting and disclosure problems identified in prior standards concerning postretirement benefits. We present several controversies that the FASB left unanswered and plans to address in the future. Accountants, financial analysts, and investor groups have a huge stake in these answers.
\end{abstract}

Keywords: postretirement benefits, postretirement accounting theory, changing postretirement measurements, changing postretirement reporting

\section{INTRODUCTION}

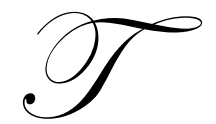

he lack of transparency in accounting and reporting for postretirement obligations has been debated for more than five decades. The first official pronouncements were issued by the Committee for Accounting Procedures (CAP) in 1956 and by the Accounting Principles Board (APB) in 1966. The Accounting Research Bulletin 47 and the APB Opinion 8 both were entitled Accounting for the Cost of Pension Plans, but addressed both pension and other postretirement benefits. These accounting standards did not require the balance sheet disclosure of any liability or asset related to retirement obligations, except under rare circumstances.

In 1980, the Financial Accounting Standards Board (FASB) attempted to improve the disclosures by pension funds and their sponsors by issuing a pair of standards, SFAS 35 and SFAS 36, respectively, both entitled Disclosure of Pension Information. Later, in 1984, the FASB issued SFAS 81, Disclosure of Postretirement Health Care and Life Insurance Benefits, which required the disclosure for postretirement benefits other than pensions. SFAS 87, Employers' Accounting for Pensions, and SFAS 88, Employers' Accounting for Settlements and Curtailments of Defined Benefit Pension Plans and for Termination of Benefits, followed in 1985 and were the most comprehensive accounting standards for accounting and reporting for pensions and their curtailment or settlement. SFAS 106, Employer's Accounting for Postretirement Benefits Other Than Pensions, issued in 1990 superceded SFAS 81 and was subsequently revised by SFAS 132, Employers' Disclosures About Pensions and Other Postretirement Benefits, in 1998, and later amended under the same title by SFAS 132R, in 2003.

Finally, SFAS 158, Employers' Accounting for Defined Benefit Pension and Other Postretirement Plans, was issued in 2006 and amended all prior standards still in existence. While FSAS 158 revises SFAS 87, 88, 106, and $132 \mathrm{R}$ reporting procedures, it does not change the recognition and measurement rules specified in these standards. Rather, SFAS 158 eliminates the practice of off the books and footnote reporting for postretirement benefit plan asset and liabilities allowed under the prior standards by requiring that these items be reported in the balance sheet.

Thus, estimates, deferrals, income and expense smoothing, and offsetting assets and liabilities are still accepted practice in accounting for postretirement benefits and are some of the major contentious issues that accountants must consider when evaluating these accounting rules. Throughout the evolution of postretirement accounting, these accounting standards have created instances where the true economic reality of a plan's 
commitment is not always accurately reported. In response, the accounting profession developed accounting and reporting rules that progressed from APB Opinion 8, which required a footnote disclosure with limited financial statement impact, to SFAS 87, which required partial representation of plan assets and obligations in the financial statements, culminating in SFAS 158, which mandated that the fair market value of postretirement benefit plan assets and obligations be included in the financial statements.

\section{UNRESOLVED ISSUES}

However, the evolutionary process is not over as the FASB prepares to make more modifications to the postretirement accounting process. Still to come are rules concerning income statement recognition, liability measurement, prescribing the rate of return and the discount rate to be used in the measurement of postretirement plan assets and liabilities, and possible consolidation of assets and liabilities on the balance sheet (Wozniak and Chittim 2005).

It is clear the FASB is poised to require a more concise postretirement accounting methodology that will prevent creativity on the part of managers who try to manipulate their financial reports. In the FASB's multiphase plan to overhaul postretirement accounting, phase two will address the following (Carpenter and Mahoney 2004):

1 Changing the format of income statement presentation which will separate the operating and non-operating components of postretirement expense;

2 Providing a more defined set of rules that govern the assumptions underlying the projected benefit obligation (PBO) calculations;

3 Determining the liability methodology that would best portray the economic reality;

4 Determining whether gross (no offsetting) or net (offsetting) position of assets and liabilities will be displayed on the balance sheet; and

5 Deciding how the FASB will deal with the interested parties such as financial analysts, politicians, regulators, and the beneficiaries.

The FASB will also consider aligning its postretirement accounting rules with those proposed by the International Accounting Standards Board (IASB). The joint initiative will work to establish new standards and has a time limit of a minimum of three years. Given the complexities of postretirement accounting, a much longer time period may be required.

\section{PURPOSE}

The purpose of this article is to examine the evolution of accounting for postretirement benefits with a focus on revealing the weaknesses of the existing rules. These weaknesses prevent the current rules to accomplish the objectives of financial reporting in the areas of transparency, representational faithfulness, and providing information to decision makers useful in evaluating the firm's cash flows and financial condition.

\section{EVOLUTION OF RECOGNITION, MEASUREMENT, ANDREPORTING RULES FOR POSTRETIREMENT BENEFITS}

\section{SFAS 87: Employers' Accounting For Pensions}

ARB 47, APB Opinion 8, and SFAS 82 all assumed that the postretirement assets and obligation belonged to the pension fund and were the rights and responsibilities of the pension fund administration. Sponsor's obligation was to fund the plan as required by law and actuarial calculations. Accordingly, only in rare circumstances and after very complex measurements required under APB Opinion 8 a sponsor reported an asset or liability in the balance sheet. In addition, in most cases, the expense reported in the income statement was equal to the amount funded. Finally, other postretirement benefits were accounted for on a pay-as-you-go basis. 
The theory underlying accounting for postretirement benefits changed dramatically when the FASB issued SFAS 87 and 88 in 1985. The recognition, measurement, and reporting rules for defined benefit pension plans required in these standards applied accrual basis of accounting when recognizing and measuring the expenses, assets, and liabilities of pension plans and remained unchanged since. While SFAS 87 required the recognition of pension expense in the income statement, the information underlying that amount was required to be disclosed in the footnotes and not reported in the financial statements (Soroosh and Espahbodi 2007). This major change in accounting practice provided more useful information to the financial statement users.

While the FASB recognized that relevant information such as the fair value of plan assets and liabilities were buried in the footnotes, it decided that complete financial statement recognition would be extreme. This lack of complete disclosure led to a lack of transparency concerning the funded status of the plans. This fact became clear when several large bankruptcies earlier this decade demonstrated that the Pension Benefit Guaranty Corporation did not have the wherewithal to cover the deficiencies in troubled plans (Miller and Bahnson 2007).

Many management assumptions and estimates are made in the prescribed calculations under SFAS 87, including the discount rate used to calculate the present value of a plan's projected benefit obligations and the expected return on plan assets. In terms of the discount rate, the rate used should be sufficient to accumulate the funding needed as of the balance sheet date to secure future cash payments to meet postretirement benefit obligations. This is left to management's discretion because different companies can have different investment strategies and different future cash requirements (Gopalakrishman and Sugrue 1995). Unfortunately, if management uses a higher discount rate the resulting present value of the obligations will be lower. This will then result in lower funding of the plan. Management is also responsible for estimating the expected return on plan assets. Based on the investment strategy of the plan, management must determine what long term yield these assets will provide. The higher the expected yield, the less the company will be required to contribute to the plan. This can also result in underfunding a defined benefit pension plan. Both of these estimates are at risk of manipulation by management (Catlin 2004).

Another shortfall in SFAS 87 is the offsetting of plan assets and liabilities. This process allows the value of the plan assets to be reduced by the liabilities of the plan and shown in the footnotes of the balance sheet as a net number (Soroosh and Espahbodi 2007). There is no other asset category on the balance sheet that is shown net of its related liability. While the FASB recognized that this was not common practice, it allowed reporting only the over or under funded status of all pension plans arguing that firms are responsible only for the funded or unfunded status of the plan and not for the plan assets or liabilities. Finally, some companies have more than one post retirement plan, each having a different level of funding. This detail is not shown in the financial statements.

\section{SFAS 106: Employers' Accounting For Postretirement Benefits Other Than Pensions}

SFAS 106 was issued in 1990 and applied accrual accounting to postretirement benefits other than pensions with specific focus on health care benefits (Soroosh and Espahbodi 2007). Historically companies had been recording and reporting these benefits on a pay-as-you-go basis using cash basis accounting. This statement now requires management to accrue the future medical costs of the employee and covered dependents during the employee's time of service. This is a monumental task which requires the use of complex actuarial assumptions and estimates. In addition, under SFAS 106 management is charged with estimating the growth rate of healthcare costs. Any reduction in this estimated growth rate would result in a reduction of the obligation, which may leave the plan underfunded.

\section{SFAS 132(R): Employers’' Disclosures About Pensions And Other Postretirement Benefits}

This statement replaced SFAS 132 and was an enhanced version with additional disclosure requirements that were intended to meet the needs of financial statement users. It focused on defined benefit pension plans and aimed to give users information about the investment strategy of the plan and explain how management determined the expected return on plan assets. The investment classifications such as debt securities, equity securities and real estate investment were required to be disclosed in the footnotes in the form of percentage break-downs. While the 
disclosure of the planned or target asset makeup was not required, it was encouraged. One drawback of this statement was that it retained the limited disclosure requirements for nonpublic entities.

\section{SFAS 158: FASB ELIMINATES OFF THE BALANCE SHEET ACCOUNTING AND REPORTING}

The FASB received many requests from users to make the postretirement benefit obligation and asset information more useful and transparent. While SFAS 87 required full disclosure in the footnotes, only those who studied pension accounting could understand it. The obvious solution was to place the information in an understandable format and move it into the body of the financial statements. Meanwhile, the SEC had specifically identified three areas of concern; the consolidation of assets and liabilities, deferral of actuarial gains and losses (smoothing), and the valuation of plan assets (Bryan, Lilien and Mooney 2007).

Users were interested in seeing the funding status of the individual post retirement plans. The current practice is to net all plan assets and liabilities and report the final number as either an asset or a liability was misleading users as to the status of individual plans. Reporting an over funded status of all post retirement plans did not mean that each individual plan was in an over funded position.

Moreover, FAS 87 calculations for pension accounting had a distorting effect on reported income (Amlie 2004). The use of the expected return on the pension assets in calculating net pension expense resulted in an understatement of pension expense and artificially increased reported income. FASB argued that the expected return on plan assets should be used due to the long term nature of these transactions and that expected gains should be recognized. Otherwise, businesses would be penalized for investing in their pension plans as opposed to investing in other long term investments.

Using the financial statements of General Electric (GE), a recent study illustrated how the use of expected return on plan assets when calculating periodic pension cost inflated a company's financial condition. In the bear market of 2001, GE's plan assets lost $\$ 2.9$ billion in value. However, GE's postretirement expense for 2001 included a $9.5 \%$ expected return on plan assets of $\$ 4.3$ billion, yielding GE a net gain from its plans of $\$ 2.1$ billion (Amelie 2004).

FASB's reasoning behind the use of estimated returns stems from the fact that postretirement benefit plans are long term liabilities that will be paid out over 30 years or more. The concept of matching dictates that the assets dedicated to pay these long term liabilities should also be invested for the long term (Amlie 2004). This view supports the use of the estimated long term return in the calculation of postretirement benefit cost assuming that in some years the actual returns will be less than expected and they will be more in other years, but in the long run, the results should approximate those obtained when the expected returns are used. The real challenge is to ensure that management is using a realistic long-term return. Unfortunately this estimate can be used to manipulate the short term financial results and wrongfully reward current management.

Users were also concerned about the estimates used by management in determining the discount rate when calculating the PBO. These calculations were intended to show the settlement amount of the plan's future obligations as of the measurement date (Soroosh and Espahbodi 2007). This determination was left to the discretion of management and had a significant affect on the income statement.

\section{SFAS 158: Purpose And Content}

There are two types of pension plans: defined benefit and defined contribution. The difference between the two is a function of what the employer has promised to its employees. Defined contribution plans require that employers contribute a certain dollar amount to an investment vehicle based on employee's payroll. Future values and the benefits derived from them will depend on investment returns in the employee's retirement account. The risk lies with the employee whereas the employer has no further obligation beyond the contribution. Defined benefit plans, on the other hand, promise a future retirement benefit determined by a benefit formula based on a wide array 
of assumptions. The ultimate cost is unknown but can be characterized as a future obligation/liability. All investment risks fall on the employer.

SFAS 158 was issued in an effort to make postretirement plans other than pensions and defined benefit pension plan information, the funded status of the plans (net liability or asset position), and their numerous parts and disclosures more transparent. SFAS 158 amended SFAS 87 and SFAS 106 by requiring the recognition of the funded status of a defined benefit and other postretirement plans in the financial statement. This was accomplished by (Epstein et al 2006):

1. Recognizing the overfunded status of postretirement obligations as an asset and the underfunded status as a liability. The status of a defined benefit plan would be measured by comparing the PBO to the fair value of plan assets and the status of other postretirement plans would be measured by comparing the accumulated benefit obligation to the fair value of assets.

2. Eliminating any transition amount not yet amortized against retained earnings, net of tax.

3. Measuring the postretirement obligation amounts at the date of the balance sheet.

4. Recognizing, as a component of comprehensive income, net of tax, the actuarial gains and losses and the prior service costs that arise over the life of the plan but have not yet been amortized. These amounts will be adjusted each year as they are amortized to the income statement through the determination of periodic postretirement benefit cost.

5. Disclosing in the notes to financial statements additional information about certain effects on net periodic benefit cost for the next fiscal year that arise from delayed recognition of the gains or losses, prior service costs or credits, and transition asset or obligation. The statement also applied to not-for-profit organizations or other entities that did not report other comprehensive income.

Thus, the FASB aimed at providing transparency to users. Prior standards failed to communicate clearly the funded status of postretirement benefit plans and the amount of short term and long term plan obligations. Users needed more information to make educated decisions and financial analysis. Ultimately, SFAS 158's impact will be to improve financial reporting and transparency by requiring companies with defined-benefit and other postretirement plans to report the current economic status of their plans and forcing them to measure their plan assets and obligations at year end. Even though the FASB did not require managers to apply the new standard retrospectively, it did recommend the practice to improve the comparability and usefulness of financial statements (Miller and Bahnson 2007).

To align its standards for postretirement benefits with that of international accounting standards, FASB will consider the future actions taken by the International Accounting Standards Board to amend FRS 17. The aim is to increase understanding of the relationship between the entity and its trustees so as to allow for better evaluation of funding obligations for postretirement benefits and the nature and extent of risks and rewards arising from the assets held by these plans.

\section{POST-SFAS 158 ACTION: PROMOTING TRANSPARENCY AND REPRESENTATIONAL FAITHFULNESS}

\section{Addressing The Possibility Of Management Manipulations}

While SFAS 158 has vastly improved postretirement benefit accounting, there is still much room for improvement. SFAS 158 did not change any SFAS 87, SFAS 88, and SFAS 106 measurement rules. Thus, management has discretion regarding what discount rate to use (Stuart 2007). Additionally, only the net amounts of plan assets and plan liabilities are reported which provides scant information regarding the health of the plan (Miller and Bahnson 2007). Also, the notes to and disclosures should be expanded to include a detailed schedule of cash outflows so that the liquidity needs of the company can be identified (Stuart 2007). These proposals ensure that the postretirement benefits are accounted for fairly and are accurately reported.

Pursuant to the measurement rules in SFAS 87, SFAS 158 adjusts actual returns to reflect expected returns with the difference recorded in Other Comprehensive Income (OCI) (Miller and Bahnson 2007). Both the expected 
rate of return on assets and the discount rate used to compute PBO are determined by management. Currently there is little accountability required by accounting standards regarding the rate of return and the discount rate selected, with some companies merely using the rates used by other companies and citing auditor approval as the reason the rate was used (Stuart 2007). If the discount rate was set at a fixed and uniform rate and the actual performance was used to compute postretirement benfit expense as opposed to being recorded in OCI, a more representationally faithful picture of the financial condition of the benefit plans would result. Also, if the plans' performances impacted income determination instead of OCI computations, management would be more likely to closely monitor the plan's investments because when the plan performed poorly earnings would be affected immediately.

Hann, Lu, and Subramanyam (2007) argued that management discretion regarding the discount rate does not impair the relevance of the PBO and that internal discretion improves communication of financial information within a company. However, at the time this study was done SFAS 158 did not exist and the return on the plan assets was not reflected in financial statements. Thus, the authors argued that managers would not be interested in manipulating items that didn't directly affect earnings. Since, under FAS 158, the discount rate directly affects earnings, management is more likely to manipulate it.

Considering uniformity versus flexibility, requiring a given discount rate for all plans to use to compute PBO would favor uniformity; however, allowing managers set the rate using relevant information would favor flexibility. Hann, Lu, and Subramanyam (2007) argue that while arbitrary uniformity will eliminate the moral hazard problem, it will also prevent the richness of the firms' economic reality from being reflected in the accounting numbers. Given the current state of financial reporting and the intense scrutiny that the profession is under, the certainty of uniformity would be preferred over the possibility of inaccurately reflecting the experiences of a plan sponsor.

Indeed, available evidence indicates that discount rates are being manipulated. According to a SEC study of 200 issuers, the discount rates used to compute PBO are on the high end and the higher the discount rate the lower the plan liability (Saroosh and Espahbodi 2007). In addition, the Pension Protection Act of 2006 requires that in 2007 companies begin using the 30-year Treasury securities rate as the discount rate when making funding decisions. If companies with benefit plans watch plan investments closely and are required to report the performance of those investments in computing postretirement benefit expenses and, ultimately, net income, the welfare of the plans and their employees will be better served.

\section{Reporting The Assets And Liabilities Of Plans Separately}

Another item of concern is that under SFAS 158 plan assets and liabilities are netted for balance sheet presentation. This can confuse financial statement users regarding the funded status and size of each plan. For example, if the plan liabilities are $\$ 1 \mathrm{M}$ and the plan assets are $\$ 2 \mathrm{M}$ an asset of $\$ 1 \mathrm{M}$ is reported. Likewise, if the plan liabilities were $\$ 100 \mathrm{M}$ and the plan assets were $\$ 101 \mathrm{M}$ an asset of $\$ 1 \mathrm{M}$ would still be reported but the users would not know from looking at the balance sheet whether the ratio of plan assets to plan liabilities was 2/1 or 101/100. When determining the health of the plan and the likelihood that the company will be able to pay the employees what it has promised; the rate of coverage of $2 / 1$ provides better information to the user than the alternative of 1.01/1.

Ideally plan assets should always equal or exceed plan liabilities. ERISA requires that plans be at least $90 \%$ funded or the company must make contributions, with some exceptions, to cover the deficiency within three to five years (Kwan 2003a and 2003b). While these regulations are beyond FASB's control, it is important to note ERISA's objectives are similar to FASB's.

\section{Reporting Expected Cash Consequences}

In addition to the disclosures required by SFAS 158, the notes should include a schedule of expected cash payments due over the life of the plan. Currently, a schedule of historical and projected benefits payments and expenses are included in the notes. However, these amounts differ from the actual amounts of cash the company may have to contribute (The Brink's Company 2005), given the funded status of each plan. 


\section{Claims Of Negative Economic Consequences}

Some have argued that SFAS 158 deters companies from providing benefits. Responding to the exposure draft preceding the issuance of SFAS 158, AIG's director of accounting policy, Anthony J. Valoroso, wrote (Letter of Comment 94, May 31, 2006) that the proposed standard may lead to suboptimal behavior by plans sponsors and that transparency can be significantly enhanced without creating an incentive for responsible companies to abandon the most secure form of delivering retirement benefits to the employee (Bryan et al 2007). If the economic reality of the benefits promised is that the company cannot provide them then the stockholders and employees need to know that. Transparency and faithful representation of reported assets and commitments of postretirement benefit plans increase the likelihood that the employees will reap the benefits they were promised.

The purpose of a company is to carry on the business in which it is engaged. One step in this process is to follow through on its commitments to their employees. Earnings should reflect the reality of these commitments. If accurately reporting the economic reality of these commitments affects a company's results to such an extent that management argues for keeping them off the financial statements, it is time to re-evaluate the competence of the management instead of changing the reporting process to keep these commitments off the books.

\section{SUMMARY AND CONCLUSIONS}

SFAS 158 moves accounting and reporting for postretirement benefits in the right direction. However, more needs to be changed so that the economic reality of these benefits are recognized and reported in financial statements. For decades, postretirement obligations were not accurately reported. Meanwhile, the Pensions Benefit Guarantee Company (PBGC), was formed in 1974 to ensure that employees received the benefits they were promised. In 2004, PBGC reported a deficit of $\$ 23.3$ billion (Schroeder 2005). It is clear that the economic reality is different than what is reported in the financial statements and the postretirement commitments made by many companies are significantly more than they can deliver.

Increased accountability in the form of accurate measurement, recording and reporting of postretirement benefits increases the odds that companies will have the ability to honor their commitments to employees and that the benefits they are offering make economic sense for the company. To accomplish the objectives of transparency and representational faithfulness and to minimize the possibility of management manipulations, FASB must standardize the discount rate used by management to compute PBO and must ensure that the actual performance of plan investments is reflected in the determination of expenses, assets, and commitments. In addition, plan assets and liabilities must be reported separately so that the status of each plan is disclosed. Finally, the disclosures must be amended to provide a clear picture of cash outflows necessary to fund the plans. Phase II of the project will hopefully address these issues and resolve them to ensure that the financial condition of the plans and their sponsors is reported fairly.

\section{RECOMMENDATIONS FOR FUTURE RESEARCH}

Future research may study the impact of recognizing plan assets and liabilities in the balance sheet on financial ratios of those companies that sponsor postretirement benefits. In addition, the impact of this recognition and improved footnote disclosures on the stock prices of sponsoring companies can be determined. Finally, the feasibility of requiring the use of a certain interest rate by all sponsors to determine plan asset returns and obligations may be explored.

\section{REFERENCES}

1. Amlie, T. T. January 2004. Finding the True Cost of pension Plans. The CPA Journal, 44-46.

2. Bryan, H. S., S. Lilien, and J. Mooney. March 2007. How the new pension accounting rules affect the Dow 30 's financial statements. The CPA Journal, 17-25.

3. Carpenter, B., and D. P. Mahoney. October 2004. Pension accounting: The continuing evolution. The CPA Journal, 24-29. 
4. Catlin, B. 2004. The trouble with pension accounting.

http://news.minnesota.publicradio.orglfeaturesI2004/11/08catlinb_nwasec.

5. Epstein, Barry, J., R. Nach, and S. M. Bragg. 2006. Wiley GAAP 2007. John Wiley \& Sons, Inc.: Hoboken, New Jersey.

6. Gopalakrishman, V., and T. F. Sugrue. 1995. The determinants of actuarial assumptions under pension accounting disclosures. Journal of Financial and Strategic Decisions 8(1): 35-41

7. Hann, R. N., Y. Y. Lu, and K. R. Subramanyam. January 2007. Uniformity versus flexibility: Evidence from pricing of the pension obligation. The Accounting Review, 82 (1): 107-137.

8. Kwan, S. June 2003a. Underfunding of private pension plans. FRBSF Economic Letter No. $2003-16$. www.frbsf.org/publications/economics/letterI2003/eI2003-16.html

9. Kwan, S. November 2003b. Pension accounting and reported earnings. FRBSF Economic Letter No. 19. www.frbsf.orglpublications/economics/letter/2003/eI200319.html

10. Miller, B. W. P., and P. R. Bahnson. May 2007. Perfect storm prompts changes in pension accounting. Journal of Accountancy, 36-42.

11. Schroeder, M. 2005. Bush Is Pushing for Pension Reform. The Wallstreet Journal January 11,2005. A2.

12. Soroosh, J., and P. Espahbodi. January 2007. New accounting rules for postretirement benefits: How SFAS 158 may affect a company's financial statements. The CPA Journal, 28-35.

13. Stuart, A. N. August 2004. Is corporate America adequately managing employee pension funds? www.cfo.com/vrintable/article.cfm/3015415/c2984379?f=ovtions

14. The Brink's Company. 2005. Annual Report - MD\&A, Primary U.S. Pension Plan. www.brinkscompany.comlar/2005AR/financial/mda/resultsofoperations/pensionplan.hml

15. Wozniak, A. and D. Chittim. 2005. FASB Pension accounting overhaul begins. Mellon Institutional Asset Management. 